\title{
KAJIAN PEDAGOGIS TENTANG TANGGUNG JAWAB GURU PAK SECARA PROFESIONAL TERHADAP PRESTASI BELAJAR PESERTA DIDIK
}

\author{
A Dan Kia \\ Universitas Kristen Indonesia \\ dannqh_dan@yahoo.co.id
}

Abstrak

Artikel ini adalah suatu kajian pedagogis secara teoritis mengenai Profesionalisme guru pendidikan agama Kristen sebagai pendidik dengan komposisi tugasnya mendidik, mengajar, membimbing, mengarahkan, melatih, menilai dan mengevaluasi peserta didik agar mencapai tujuan pembelajaran serta menghasilkan prestasi belajar sesuai yang diharapkan. Yesus sebagai teladan bagi guru pendidikan agama Kristen, harus menjadi ukuran bagi setiap pendidik Kristen. Dengan meneladaniNya, maka akan berdampak dalam pekerjaan selama proses pembelajaran berlangsung dan akan menghasilkan prestasi bagi peserta didik. Prestasi belajar yang diharapkan merupakan suatu keberhasilan selama proses pembelajaran berlangsung. Hal ini merupakan tanggungjawab seorang guru pendidikan agama Kristen yang secara profesional memberikan waktu dan kemampuan dirinya dalam mendidik, dan memberikan motivasi belajar agar mencapai suatu prestasi dalam bagi setiap peserta didik.

Dalam menjalankan tugasnya sebagai pendidik, guru pendidikan agama Kristen harus dapat meningkatkan kompetensi serta berkewajiban untuk merencanakan pembelajaran secara baik, mengembangkan kualifikasi dan kompetensinya secara berkesinambungan. Guru yang menjalankan tugasnya dengan baik disebut guru yang profesional, yakni guru yang memiliki beberapa keahlian atau kompetensi meliputi pedagogik, kepribadian, sosial, dan profesional yang terjalin satu dengan lainnya. Untuk mencapai apa yang menjadi tujuan dari penulisan ini, maka penulis menggunakan metode kualitatif sebagai studi pustaka dan didukung oleh beberapa refensi secara online untuk kelengkapan dan penyempurnaan tulisan ini.

Penelitian ini mengasilkan suatu kesimpulan bahwa kinerja secara profesional seorang guru sangat berpengaruh terhadap pencapaian prestasi bagi setiap peserta didik dalam dunia pendidikan. Secara khusunya bagi guru pendidikan agama Kristen sebagai pembawa kebenaran dan motivator yang disertai dengan kekuatan spiritual, dapat membangkitkan semangat belajar sebagai wujud dari iman yang berkaitan dengan tindakan, sehingga menghasilkan prestasi yang berdampak positif bagi guru yang profesional dalam hal mengajar, mendidik dan memberi motivasi terhadap peserta didik.

Kata kunci: Tanggungjawab dan Profesional Guru 


\section{A. Pendahuluan}

Pendidikan menghasilkan perubahan. Perubahan berdampak bagi masa depan setiap peserta didik yang terlibat dalam proses pembelajaran. Salah satu faktor penting yang dapat menentukan keberhasilan belajar mengajar pada suatu sekolah adalah tingkat profesionalisme guru dalam menjalankan tugas-tugas pengajarannya. Dewasa kini, lembaga pendidikan sebagai wadah pembentukan karakter untuk suatu perubahan dan peningkatan kualitas pendidikan menunjukkan peningkatan yang baik, akan tetapi tidak semua lembaga pendidikan atau sekolah belum dapat merealisasikan tujuan pendidikan yang sesuai dengan tujuan pendidikan nasional, yakni mencerdaskan kehidupan bangsa dan mengembangkan manusia Indonesia seutuhnya, yaitu manusia yang beriman dan bertaqwa terhadap Tuhan yang Maha Esa dan berbudi pekerti luhur, memiliki pengetahuan dan keterampilan, kesehatan jasmani dan rohani, kepribadian yang mantap dan mandiri serta rasa tanggung jawab kemasyarakatan dan kebangsaan. Hal tersebut merupakan suatu wacana pemerintah agar tercapainya tujuan pendidikan secara nasional melalui setiap lembaga atau sekolah yang ada, namun terkadang pendidikan yang dilaksanakan belum tercapai tujuan pendidikan seutuhnya dikarenakan kurang profesionalnya guru dalam mengajar.

Hal ini juga berlaku bagi guru pendidikan agama Kristen atau disingkat guru PAK. Keahlian dan kemampuan guru pada umumnya juga terdapat dalam lingkup pendidikan Kristen. Sehingga tidak secara profesional guru PAK melaksanakan tugas mengajarnya dengan baik sesuai standar yang diinginkan dalam lingkungan pendidikan.

\footnotetext{
${ }^{1}$ Homrighausen, E. G. \& Enklaas, (Jakarta: BPK Gunung Mulia, 1990), 165.
}

Kurangnya kemampuan seorang guru PAK dalam hal mengajar, disebabkan karena adanya perkembangan dunia pendidikan yang sejalan dengan kemajuan teknologi dan globalisasi yang begitu cepat, perlu diimbangi oleh kemampuan pelaku utama pendidikan, dalam hal ini guru. Bagi sebagian guru, menghadapi perubahan yang cepat dalam pendidikan dapat membawa dampak kecemasan dan ketakutan, sehingga yang diharapkan dalam tujuan pendidikan secara nasional tidak akan terwujud karena banyak kekurangan menyangkut keahlian seorang guru.

Profesionalisme tidak hanya hadir dalam bentuk tulisan, tetapi harus ditunjukkan dalam bentuk kerja yang nyata dalam proses belajar mengajar. Hal ini harus menjadi suatu kenyataan jika akhirnya peserta didik menghasilkan prestasi belajar yang memuaskan. E. G. Homrighausen \& Enklaar mengatakan bahwa "guru dalam pendidikan agama sangat penting karena ia dipanggil untuk membagikan harta abadi, dalam tangannya ia memegang kebenaran Ilahi dan dalam pekerjaannya ia menghadapi jiwa manusia yang besar nilainya di hadapanAllah"

Pemahaman di atas memberikan suatu pengertian bahwa guru PAK bukan saja memiliki kemampuan secara umum, tetapi secara khusus adanya suatu keahlian yang dapat berdampak bagi pendidikan, karena memiliki pengaruh untuk meningkatkan prestasi belajar peserta didik dengan nilai yang dimiliki atau hikmat yang didapatinya dari Tuhan sesuai talenta yang ada pada dirinya, sehingga tujuan Pendidikan yang ingin dicapai dapat terwujud dengan baik. Hal ini juga diwujudnyakan oleh pemerintah yang adalah wakil Tuhan terhadap lingkungan Pendidikan. 
Untuk mencapai tujuan pendidikan nasional yang diwujudnyatakan melalui setiap sekolah-sekolah yang ada, maka pemerintah dengan berbagai upaya yang dilakukan meningkatkan profesionalisme guru dengan cara pemberian sertifikasi guru, pengangkatan tenaga honorer menjadi Calon Pegawai Negeri Sipil (CPNS), dan sebagainya. Semua upayaupaya tersebut agar para guru secara umum dan khususnya bagi guru PAK lebih profesional menjalankan tugas-tugasnya yang sudah dilaksanakan untuk peningkatan profesionalisme diri dari setiap guru. Tingkat profesionalisme guru dalam menjalankan tugas-tugasnya dapat terlihat dari tingkat prestasi belajar peserta didik yang diperolehnya dalam mengikuti proses belajar mengajar di kelas.

Dewasa kini masih terdapat banyak pendidik yang memiliki keterbatasan atau keterampilan dalam hal mengajar secara baik. Seharusnya perlu disadari bahwa guru PAK adalah tenaga profesional yang memiliki keahlian, didukung dengan strategi menggunakan metode mengajar sesuai kemampuan yang dimilikinya. Guru PAK yang profesional adalah seorang pribadi yang memiliki kemampuan diri sebagai pekerja keras untuk mencapai keberhasilan dalam mendidik peserta didik.

Hal ini dikarenakan guru PAK hanya mengerjakan suatu pekerjaan secara rutinitas setiap hari yakni mengajar, tetapi tidak memikirkan bagaimana meningkatkan kinerja yang profesional untuk menghasilkan prestasi yang berdampak bagi peserta didik. Jika guru PAK menyadari akan hal ini, maka secara profesional kerja guru dapat memberikan prestasi belajar bagi para peserta didik. Seharusnya dengan adanya Pendidikan, maka akan timbul dalam diri seseorang untuk berlomba-lomba dan memotivasi diri agar lebih baik dalam meningkatkan kinerja secara professional disegala aspek kehidupan. Pendidikan merupakan salah satu syarat untuk mencapai perubahan dan meningkatkan prestasi belajar sehingga tujuan Pendidikan dapat dicapai sesuai yang diharapkan.

Salah satu poin penting yang harus dilaksanakan oleh guru PAK dalam proses pembelajaran di sekolah adalah dapat menghasilkan prestasi bagi setiap peserta didik dibawa tanggungjawabnya. Prestasi merupakan hasil belajar yang dicapai setelah melalui proses kegiatan belajar mengajar. Prestasi dapat ditunjukkan melalui nilai yang diberikan oleh seorang guru dari jumlah bidang studi yang telah dipelajari oleh peserta didik, seperti hasil belajar yang dibagikan pada setiap akhir semester. Setiap kegiatan pembelajaran tentunya selalu mengharapkan terjadinya pembelajaran yang maksimal. Dalam proses pencapaiannya, prestasi belajar sangat dipengaruhi oleh berbagai faktor. Salah satu faktor utamanya adalah keberadaan guru. Mengingat keberadaan guru dalam proses kegiatan belajar mengajar sangat berpengaruh, maka sudah semestinya kualitas guru PAK harus diperhatikan. Dengan demikian, maka guru PAK bukan saja ahli dalam bidang spiritual, tetapi juga memiliki kemampuan dalam berbagai strategi mengajar, dengan memiliki kemampuan dalam mempergunakan metode yang sudah didisain untuk suatu proses pembelajaran yang berinovasi dan kreatif didukung dengan mutu yang berkualitas.

Upaya untuk meningkatkan mutu pendidikan yang pertama adalah meningkatkan kualitas seorang guru. Oleh karena itu profesionalisme seorang guru di sini sangat dibutuhkan. Guru profesional yang dimaksud adalah guru yang berkualitas, berkompetensi, dan guru yang dikehendaki untuk mendatangkan prestasiprestasi belajar. Dengan demikian, maka guru PAK merupakan seorang pribadi professional, juga harus mampu 
mempengaruhi proses belajar mengajar bagi peserta didik, yang nantinya akan menghasilkan prestasi belajar memuaskan.

\section{B. Hakikat Profesionalisme Guru PAK}

Beranjak dari hakikat profesionalisme guru PAK, maka harus berkaca pada Alkitab sebagai sumber pengetahuan yang dapat memberikan teladan melalui hal-hal kebenaran bagi seseorang yang ingin berkarya dalam dunia pendidikan dan juga sebagai guru profesional. Yesus sebagai Guru Agung yang juga sebagai contoh dan tokoh utama yang harus diteladani oleh pendidik Kristen masa kini, karena PAK tidak terlepas dari Sang Guru Agung, yaitu Tuhan Yesus Kristus, Yohanes 3:2.

Teladan yang diberikan Yesus sebagai Guru Agung, menggambarkan bahwa Dialah Guru Agung yang tidak ada bandingnya sebagai guru yang profesional. Patokan dari seorang guru profesional ialah pada Yesus Kristus sang Guru Agung. Yesus memiliki cara mengajar yang sempurna dengan kualitas diri yang berdampak dalam setiap pengajaran-Nya. Yesus memiliki strategi dan metode mengajar yang dapat dipahami oleh setiap pengikut-Nya

Yesus menjadi teladan dalam siklus pengajaran dan memiliki kemampuan yang sempurna secara istimewa. Hal ini seperti yang dikatakan oleh Harianto GP bahwa "Yesus mengajar dengan cara yang sangat istimewa. Yesus senantiasa menyatakan diri sebagai guru yang tidak ada taranya karena Dia adalah kebenaran" 2 Kualifikasi sebagai kristeria utama bagi seorang guru PAK, juga ada dalam pribadi Yesus sebagai Guru Agung.

Kemampuan seorang guru dalam

\footnotetext{
${ }^{2}$ Harianto GP, Pendidikan Agama Kristen Dalam Alkitab \& Dunia Pendidikan Masa Kini (Yogyakarta: ANDI, 2012), 38.
}

tugas dan tanggungjawabnya, merupakan bagian dari profesionalisme kinerja guru. Untuk memahami dan menjalankan tugasnya dengan baik, maka seorang guru harus memiliki kualifikasi sebagai tenaga profesional, dan hal ini dapat cermati sebagai berikut:

1. Tingkat capable personal, maksudnya guru diharapkan memiliki pengetahuan, kecakapan, dan keterampilan serta sikap yang lebih mantap dan memadai sehingga mampu mengolah proses belajar mengajar secara efektif.

2. Guru sebagai inovator, yakni sebagai tenaga kependidikan yang memiliki komitmen terhadap upaya perubahan dan reformasi.

3. Guru sebagai developer, guru harus mempunyai visi keguruan yang mantap dan luas. ${ }^{3}$

Pemahaman di atas memberikan suatu pengertian bahwa kualifikasi sebagai suatu standar di mana guru PAK perlu memiliki keahlian dalam dunia pendidikan, khususnya dalam hal mengajar. Dalam dunia pendidikan, kualifikasi dimengerti sebagai keahlian atau kecakapan khusus dalam bidang pendidikan, baik sebagai pengajar mata pelajaran, administrasi pendidikan, dan seterusnya. Bahkan, kualifikasi terkadang dapat dilihat dari segi derajat lulusannya. Seperti dalam Undang-undang Sisdiknas 2003, ditetapkan bahwa untuk menjadi guru sekolah dasar (SD) harus lulusan strata satu (S1). Guru merupakan suatu profesi yang intinya suatu jabatan atau pekerjaan yang memerlukan keahlian khusus sebagai guru. Kualifikasi guru adalah keahlian yang diperlukan untuk melakukan pekerjaannya melalui pendidikan khusus keahlian.

Guru yang qualified adalah guru

${ }^{3}$ A. M. Sardiman, Interaksi dan Motivasi Belajar Mengajar (Jakarta: Rajawali Pers), 67. 
yang memenuhi kualifikasi pendidikan yang telah ditetapkan berdasarkan ketentuan yang berlaku. Guru PAK yang profesional harus memenuhi kriteria dari segi kualifikasi dan kompetensi yang dibuktikan dengan sertifikat profesional. Artinya guru pada tiap satuan pendidikan harus memenuhi kualifikasi akademik dengan bidang keilmuan yang relevan sesuai bidang studi atau mata pelajaran yang mereka ajarkan di sekolahnya, sehingga mereka disebut kompeten untuk bidang pekerjaannya, yakni mendidik, mengajar, dan melatih. Dalam kegiatan belajar-mengajar guru dipandang sebagai titik sentral dalam proses belajar mengajar dan merupakan unsur pelaksana utama yang paling menentukan berhasil atau tidaknya proses dan tujuan pengajaran.

Guru sebagai pendidik harus dapat memenuhi persyaratan profesionalnya, antara lain yaitu: kemampuan mengajar sebab guru profesional adalah guru yang dapat menguasai dan mengembangkan materi pelajaran sesuai kompetensi yang dimilikinya. Dengan demikian mutu pendidikan dapat terwujud dengan baik. Seperti ditulis oleh Djauzak Ahmad bahwa peningkatan mutu pendidikan. Antara lain sebagai berkut:

1) Guru yang bermutu,

2) Sarana dan prasarana pendidikan yang memadai,

3) Pengelolaan sekolah yang profesional,

4) Proses belajar mengajar yang efektif,

5) Pengelolaan dana yang baik,

6) Supervisi dan monitoring,

7) Hubungan sekolah dengan masyarakat. $^{4}$

Ketujuh hal tersebut merupakan komponen pokok dari semua komponen

\footnotetext{
${ }^{4}$ Djauzak Ahmad. Petunjuk Peningkatan Mutu Pendidikan di Sekolah Dasar. Depdikbud.

Dirjen Pendidikan Dasar dan Menengah. Direktorat Dasar. 9.

${ }^{5}$ Sukamto, Dkk. from. http://www.infodiknas.com /217-pengembangan-profesi-guru-secara-
}

pendidikan, maka untuk meningkatkan kualitas pendidikan komponen tersebut perlu diperhatikan secara sistematis. Dalam ketentuan umum UU No. 14 Tahun 2005 tentang Guru dan Dosen dinyatakan bahwa guru adalah pendidik profesional dengan tugas utama mendidik, mengajar, membimbing, mengarahkan, menilai dan mengevaluasi peserta didik pada berbagai jenjang dan jenis pendidikan formal. Selanjutnya untuk menjamin keterlaksanaan tugasnya yang utama tersebut, Pasal 8 undang-undang yang sama mensyaratkan guru wajib memiliki kualifikasi akademik, kompetensi, sertifikat pendidik, sehat jasmani dan rohani, serta memiliki kemampuan untuk mewujudkan tujuan pendidikan nasional. Untuk itu dilaksanakanlah program peningkatan kualifikasi dan sertifikasi guru sejak tahun 2006/2007 di semua jenjang dan jenis pendidikan formal. Terlepas dari ekses negatif yang muncul, kedua program tersebut merupakan komponen penting dalam road map kebijakan menuju profesionalisme guru, yang juga diikuti dengan beberapa penelitian yang terkait. ${ }^{5}$

Guru sebagai salah satu komponen pendidikan di sekolah dapat dikatakan sebagai faktor yang sangat penting, seperti diungkapkan Oteng Sutrisna, yaitu: kualitas program pendidikan bergantung tidak saja pada konsep-konsep program yang cerdas tetapi juga pada personel pengajar yang mempunyai kesanggupan dan keinginan untuk berprestasi. Tanpa personel yang cakap, efektif, program pendidikan yang dibangun atas konsepkonsep yang cerdas serta dirancang dengan teliti pun tidak berhasil. ${ }^{6}$ Guru adalah

berkesinambungan-sebagai-strategi-nasionalpendukung-sertifikasi-guru/, diakses pada tanggal 18 Agustus 2019, pukul 17:40 WIB.

${ }^{6}$ Oteng Sutisna. Administrasi Pendidikan Dasar Teoritis untuk Praktek Profesional (Bandung: Penerbit Angkasa, 2016), 109. 
faktor tunggal yang paling menentukan terhadap kualitas pendidikan. Oleh karena itu, guru harus memiliki kemampuan profesional yang memadai demi keberhasilan proses belajar mengajar. Guru yang profesional adalah guru yang memiliki kemampuan intelegensi dan berprestasi dalam bekerja. Jadi guru yang memiliki prestasi tinggi dalam bekerja merupakan salah satu ciri dari guru yang berkualitas, sedangkan menurut Zahara Idris bahwa guru yang profesional diperlukan memiliki 12 kompetensi dasar yaitu:

1) Mengembangkan kepribadian,

2) Menguasai materi pelajaran,

3) Mengelola program belajar mengajar

4) Mengelola kelas,

5) Menggunakan media dan sumber belajar,

6) Menguasai landasan kependidikan,

7) Mengelola interaksi belajar mengajar,

8) Menilai prestasi belajar peserta didik,

9) Mengenali fungsi dan program pelayanan bimbingan dan pelayanan,

10) Mengenal dan menyelenggarakan administrasi sekolah,

11) Memahami prinsip-prinsip dan penafsiran hasil penelitian,

12) Interaksi dengan teman sejawat dan masyarakat. $^{7}$

Seiring dengan berkembangnya ilmu pengetahuan dan teknologi juga dalam rangka otonomi pendidikan, maka peranan guru sebagai pendidik, pengajar, dan pelatih sangat memerlukan kreatifitas yang tinggi. Melalui hal ini, maka kembali kepada pribadi setiap guru agar memahami strategi bagaimana cara menyajikan pelajaran yang menarik, mengembangkan materi pelajaran yang akan disajikan untuk

\footnotetext{
${ }^{7}$ H. Zahara Idris dan H. Lisma Jamal, Pengantar Pendidikan, Jilid I (Jakarta: Grasindo), 55-60.

${ }^{8}$ Nana Sujana, Cara Belajar Peserta didik Aktif dalam Proses Belajar Mengajar (Bandung: Rosda Karya, 2009), 42.
}

peserta didik yang cocok dengan kebutuhan masyarakat, melaksanakan program evaluasi, menganalisis hasil evaluasi, membimbing peserta didik yang memiliki kesulitan belajar, mencari sumber belajar yang sesuai dengan kebutuhan masyarakat, melatih peserta didik dalam kegiatan ekstrakurikuler, dan lain-lain. Menurut Nana Sudjana, tugas guru sangat kompleks yang meliputi: (a) merumuskan tujuan pengajaran, (b) menetapkan alat evalusai, c) menetapkan bahan pelajaran, (d) menetapkan kegiatan belajar mengajar, (e) menetapkan metode dan alat pelajaran, ${ }^{8}$ sedangkan Uzer Usman mengatakan bahwa tugas guru di kelompokkan menjadi 3 macam yaitu: tugas di bidang profesi tugas di bidang kemanusiaan dan tugas di bidang kemasyarakatan. ${ }^{9}$ Tugas di bidang profesi meliputi tugas mendidik, mengajar, dan melatih. Tugas di bidang kemanusiaan, bahwa guru di sekolah sebagai orangtua kedua. Guru harus mampu menarik simpati sehingga menjadi idola bagi peserta didiknya, sedangkan tugas di bidang kemasyarakatan, guru hendaknya dapat menjadi panutan masyarakat yang turut serta mencerdaskan kehidupan bangsa.

Profesi adalah kata benda yang diambil dari bahasa Inggris yaitu "Profession" dan punya turunan professionalisasi (a) professionalisme (b) dalam bahasa Inggris secara berturut-turut adalah Profesional, profesionalization dan profesionalisme. ${ }^{10}$ Studi masalah profesionalisme mendorong untuk berkenan dengan sejumlah definisi profesi yang dikemukakan oleh Webter's New Word Dictionary profesi adalah "suatu pekerjaan yang meminta pendidikan yang

\footnotetext{
${ }^{9}$ Moch. Uzer Usman, Menjadi Guru Profesional (Bandung: Rosda Karya), 42.

10 H. Agustiar Syah Nur, Profesionalisme Manajemen Tenaga Pendidikan (Padang: Agustus 1 Makalah Ini Disampaikan Pada Pertemuan Ilmiah Manajemen Pendidikan).
} 
tinggi dalam liberal arts dan science dan biasanya meliputi pekerjaan mental bukan pekerjaan manual" 11 Kemudian Good's Dictionary of Education mendefinisasikan profesi "Suatu pekerjaan yang meminta persiapan spesialisasi yang relatif lama di perguruan tinggi dan dikuasai oleh kode etik khusus." 12 dari kedua definisi tersebut sudah jelas bahwa tidak semua pekerjaan disebut profesi. Profesi mengandung unsur pengabdian karena profesi bukan dimaksudkan untuk mencari keuntungan bagi diri sendiri baik dalam ekonomis maupun psikis, melainkan untuk pengabdian masyarakat. Hal ini berarti bahwa tidak boleh sampai merugikan, merusak atau menimbulkan malapetaka bagi masyarakat. Sebaliknya profesi itu harus berusaha menimbulkan kebaikan, keberuntungan, kesempurnaan atau kesejahteraan bagi masyarakat.

Suatu profesi erat kaitannya dengan jabatan atau pekerjaan tertentu yang dengan sendirinya menuntut keahlian, pengetahuan dan keterampilan tertentu pula. Dalam pengertian profesi telah tersirat adanya suatu keharusan kompetensi agar profesi itu berfungsi dengan sebaik-baiknya. Menurut Suharsimi Arikunto, bertumpu dari definisi profesi dapat dilihat bahwa:

1) Di dalam suatu pekerjaan professional diperlukan teknik serta prosedur teknik serta prosedur yang bertumpu pada landasan intelektual yang dipelajari dari suatu lembaga, kemudian diterapkan di masyarakat untuk pemecahan suatu masalah

2) Seorang pekerja professional dapat dibedakan dengan seorang pekerja teknisi dalam hal pemilihan filosofi yang kuat untuk mempertanggung jawabkan pekerjaannya.

3) Seorang yang bekerja berdasarkan

11 Oteng Sutisna, Profesionalisme Pekerjaan Kepala Sekoah (Bandung: Depdikbud, 2009), 3.

12 Ibid., 3. profesinya memerlukan teknik dan prosedur yang ilmiah serta memilliki dedikasi yang tinggi dalam menyikapi lapangan pekerjaan yang berdasarkan atas sikap seorang ahli. ${ }^{13}$

Jadi, profesionalisasi adalah suatu proses perubahan status non-profesi yang didapat dipakai untuk proses yang dinamis dalam pekerjaannya.

\section{Karakteristik Profesi}

Profesi adalah pekerjaan, namun tidak semua pekerjaan adalah profesi. Profesi mempunyai karakteristik yang membedakannya dari pekerjaan lain. Profesi adalah pekerjaan yang membutuhkan pelatihan dan penguasaan terhadap suatu pengetahuan khusus. Suatu profesi biasanya memiliki asosiasi profesi, kode etik, serta proses sertifikasi dan lisensi yang khusus untuk bidang profesi tersebut. Contoh profesi adalah pada bidang hukum, kedokteran, keuangan, militer, teknik, desainer, dan tenaga pendidik. Bagian-bagian ini yang harus dimengerti dalam suatu profesi secara professional dalam suatu pekerjaan yang didukung oleh tunjangan sesuai kemampuan atau keahlian dalam suatu profesi.

Profesi memiliki ciri khusus yang di dalamnya tercapat suatu skill yang dapat menunjang pekerjaan seseorang karena memiliki keahlian yang dapat diandalkan. Untuk memahami tentang karakteristik dari suatu profesi, maka beberapa ahli memberikan suatu definisi dengan mengemukakan batasan-batasan atau ciri dalam suatu profesi. Chandler mencoba menerapkan ciri-ciri profesi dalam bidang pendidikan bagi para guru, ia mengemukakan ciri-ciri guru sebagai profesi adalah:

\footnotetext{
${ }^{13}$ Suharsimi Arikunto, Management Pengajaran secara Manusiawi (Jakarta: Rineka Cipta), 223.
} 
1) Mengutamakan layanan sosial lebih dari kepentingan pribadi.

2) Mempunyai status yang tinggi.

3) Memiliki pengetahuan yang khusus (dalam hal mengajar dan mendidik).

4) Memiliki hak memperoleh standar kualifikasi professional.

5) Memiliki kode etik profesi yang ditentukan oleh organisasi profesi. ${ }^{14}$

Robert W. Richey dalam bukunya yang berjudul, Profil Pendidik Profesional mengemukakan ciri guru sebagai suatu profesi adalah sebagai berikut:

1) Adanya komitmen dari para guru bahwa jabatan itu mengharuskan pengikutnya menjunjung tinggi harkat martabat manusia lebih daripada mencari keuntungan diri sendiri.

2) Suatu profesi mensyaratkan orangnya mengikuti persiapan profesional dalam jangka waktu tertentu.

3) Harus selalu menambah pengetahuan agar terus menerus bertumbuh dalam jabatannya.

4) Memiliki otonomi tinggi, artinya guru memiliki kebebasan yang besar dalam melakukan tugasnya karena mempunyai tanggungjawab moral yang tinggi.

5) Memiliki kemampuan intelektual untuk menjawab masalah yang dihadapi.

6) Selalu ingin belajar terus menurut bidang keahlian yang ditekuni.

7) Memiliki kode etik.

8) Menjadi anggota dari suatu profesi.

9) Jabatan itu dipandang sebagai suatu karir hidup. ${ }^{15}$

Pengertian profesi dan ciri-ciri guru sebagai suatu profesi, maka dapat dibedakan mana kegiatan atau pekerjaan professional. Pekerjaan mengajar termasuk pekerjaan profesional karena

14 Piet A. Sahertian 1994. Profil Pendidik Profesional, (Yogyakarta: Andi Offset) 27-28.

15 Piet A. Sahertian, Profil Pendidik Profesional (Yogyakarta: Andi Offset), 35. mengharuskan adanya suatu keahlian khusus dalam melakukan pekerjaan. Sutaryadi menjelaskan bahwa guru sebagai tenaga profesional memiliki ciri-ciri sebagai berikut:

1) Kependidikan profesional berdasarkan pada keahlian teknik yang diperoleh melalui pendidikan dan latihan secara intensif

2) Memiliki pelayanan pada klien

3) Di samping memiliki norma pelayanan terdapat pula norma-norma yang menentukan hubungan antara profesional dengan klien

4) Berorientasi pada kelompok, yaitu pada kolega yang berpengetahuan dan berkompetensi bidang yang bermanfaat untuk membuat keputusan

5) Performance dikendalikan terutama oleh dirinya sendiri serta dari pengamatan teman sekelompok. ${ }^{16}$

Piet A. Sahertian mengemukakan makna professional dapat dipandang dari tiga dimensi, yaitu: (1) Ahli / Expert, (2) Rasa tanggung jawab, (3) Memiliki rasa kejawatan. ${ }^{17}$ Ahli / Expert, guru adalah orang yang ahli dalam tugas mendidik selain menguasai isi pengajaran yang akan diajarkan, tetapi juga mampu menanamkan konsep mengenai pengetahuan yang diajarkan.

Mengajar merupakan sarana untuk mendidik, untuk menyampaikan pesanpesan yang berguna. Guru yang ahli dalam mengajar dan mengerti bahwa mengajar itu suatu seni, maka tidak mustahil akan menciptakan situasi belajar mengajar yang mengandung arti relasi interpersonal. Situasi ini harus diciptakan bagi subyek didik yang merasa diperhatikan dan dihargai sehingga mempunyai jati diri.

Dalam hal ini, terlihat adanya tekanan positif bagi peserta didik untuk

${ }^{16}$ Sutaryadi, Administrasi Pendidikan, Riset dan Prakits (Surabaya: Usaha Nasional), 6.

${ }^{17}$ Piet A. Sahertian, Op. Cith.30-31. 
mengembangkan akitivitas belajar mencakup segala aspek sesuai kemampuannya masing-masing. Guru PAK sebagai tenaga professional diharapkan dapat mempergunakan waktu sesuai dengan keahlian yang dimilikinya, dan mempersiapkan bahan ajar dengan baik, bertanggung jawab di setiap waktu dan kesempatan yang ada agar jangan terbuang kesempatan dalam mengelola waktu bekerja (Efesus 5:16). Hal ini merupakan bentuk profesionalisme seorang guru yang didukung dengan moralitas menyangkut kode etik dalam bekerja.

Pada umumnya orang memberikan arti sempit pada pengertian profesional. Sering diartikan sebagai suatu keterampilan teknis yang dimiliki seseorang, tetapi H. Agustiar Syah Nur mengemukakan bahwa karakteristik tenaga yang profesional harus meliputi hal-hal berikut ini:

1) Pendidikan/Keahlian Khusus

2) Keterampilan (Skill)

3) Legalitas

4) Standar Pekerjaan

5) Fasililtas dan peralatan

6) Disiplin

7) Tanggung jawab

8) Penelitian (Research)

9) Organisasi Profesi

10) Sumber Penghasilan Utama

11) Sikap (Attitude). ${ }^{18}$

Pendidikan/ keahlian khusus, seorang yang dikatakan profesional dalam melaksanakan tugasnya didasarkan atas prinsip-prinsip ilmu pengetahuan di bidang tertentu yang diperolehnya melalui proses pendidikan, setiap keputusan serta kebijakan yang dibuatnya di dasarkan pada kaidah-kaidah keilmuannya. Seorang pekerja profesional tidak dapat digantikan oleh orang lain kecuali oleh penyandang keahlian yang sama.
Keterampilan, seorang pekerja profesional dituntut untuk memilliki keterampilan-keterampilan yang menunjang dari profesinya, karena seorang akan diakui sebagai pekerja yang profesional apabila secara teori memang memiliki keterampilan teknis atau skill. Pekerja profesional di samping mempunyai aspek prinsip atau konsep teori harus dibarengi dengan keunggulan dalam mengaplikasi ilmu-ilmu yang didapatnya melalui pelatihan, pendidikan ataupun kursus yang memberikan kekhususan pada pekerja yang profesional. Legalitas, seorang pekerja profesional harus mengetahui prosedurprosedur tertentu terhadap keprofesionalan yang dimiliki, ia bekerja setelah mengetahui atau melalui prosedur tertentu, sehingga seorang professional dapat menjadi proteksi bagi masyarakat pemakai jasa. Standar pekerjaan seorang yang profesional dapat dilihat melalui ijazah yang diperolehnya dengan mengikuti pendidikan ataupun pelatihan yang memadai, kemudian mendapatkan izin secara syah dalam melaksanakan tugas profesinya secara profesional yang menunjukkan kualitas kerjanya, out put yang dihasilkan baik, serta dalam melaksanakan tugasnya mendapat pengawasan guna melihat hasil kerjanya.

Profesionalitas seorang pendidik menjadi tolak ukur dalam pekerjaannya, sehingga hasil yang dikerjakan berjalan secara efektif dan efesien sesuai tujuan yang diharapkan. Hal ini menjadi suatu ciri khas menyangkut disiplin diri yang profesional dengan memanfaatkan waktu yang ada sebaik mungkin.

Profesi merupakan bagian dari organisasi. Organisasi profesi adalah organisasi yang anggotanya adalah para praktisi yang menetapkan diri mereka sebagai profesi dan bergabung bersama

\footnotetext{
${ }^{18}$ H. Agustiar Syah Nur. Op.Cit., 3.
} 
untuk melaksanakan fungsi-fungsi sosial yang tidak dapat mereka laksanakan dalam kapasitas mereka sebagai individu. Organisasi profesi adalah suatu wadah yang di dalamnya terdiri atas orang-orang yang memiliki keahlian, karena di dalam organisasi tersebut mereka saling bertukar pikiran dan berkomunikasi dengan para professional dalam bidang keahlian yang sama. Di dalam organisasi profesi, adanya dukungan sesuai kemampuan yang berkualitas dan memiliki penghasilan utama sesuai kemampuan atau keahlian yang dimilikinya secara professional.

Kriteria atau ciri-ciri seorang profesional sebagaimana yang diungkap di atas tentu tidak merupakan hal-hal yang absolute dan tidak merupakan suatu keutuhan lengkap pada diri seorang. Ia merupakan kombinasi dengan kadar masing-masing karakteristik yang relatif berbeda pada diri setiap orang. Dengan kata lain kualitas profesional seseorang ditentukan oleh kadar masing-masing karakteristik yang secara konsisten ditampilkan oleh orang tersebut, sehingga kombinasi dan konsisten akan dipersepsi orang lain sebagai sosok yang profesional.

Sesuai dengan hakekat profesi dan kriteria profesional, maka sudah jelaslah bahwa pekerjaan guru harus dilakukan oleh orang selaku guru, bahwa pekerjaan guru penuh pengabdian kepada masyarakat, sebagai konsekuensi logis dari pertimbangan tersebut, maka setiap guru harus mempunyai kekhususan, kekhususan itu mempunyai kelengkapan mengajar, mengajar memerlukan seni dan keterampilan, tidak semua orang mampu mendidik secara sempurna, dan untuk mengarah kepada tingkat kesempurnaan berarti setiap guru dapat mengadakan uji coba terhadap anak didiknya atau dengan kata lain lapangan kerja keguruan tidak dapat dilaksanakan berdasarkan amatirisme dengan dasar coba-coba. Lapangan kerja ini memerlukan perencanaan yang mantap yaitu suatu manajemen yang memperhitungkan komponen sistemnya.

Pengakuan terhadap lapangan kerja guru sebagai profesi adalah tepat karena lapangan kerja ini memerlukan dukungan ilmu atau teori yang memberikan konsepsi ilmu pendidikan dengan cabangcabangnya, lebih-lebih bila diingat bahwa pendidikan berorientasi pada pengembangan ketiga aspek yaitu kognitif, afektif, dan psikomotor. Seorang guru diharapkan dapat mematangkan dan mengembangkan ketiga aspek tersebut secara profesional. Pendidikan tidak hanya sekedar mengasah aspek kognitif dengan mengabaikan salah satu aspek tersebut berarti memperkecil kemungkinan terbentuknya manusia utuh yang kelak diharapkan mampu mandiri di tengahtengah masyarakat, sehingga mempunyai tanggung jawab terhadap peserta didik, dan tercapai atau tidaknya tujuan pendidikan sangat ditentukan oleh kemampuan guru dalam mengaplikasikan sebagian besar kemampuan mengajarnya yang sering disebut "sepuluh kompetensi guru" yang harus dimiliki dan dilaksanakan dalam rangka melaksanakan tugasnya.

\section{Profesional Kerja Guru}

Menjadi profesional, berarti menjadi ahli dalam bidangnya, sehingga seorang ahli, tentunya harus berkualitas dalam melaksanakan pekerjaannya. Akan tetapi tidak semua Ahli dapat menjadi berkualitas. Hal ini dikarenakan menjadi berkualitas bukan hanya persoalan ahli, tetapi juga menyangkut persoalan integritas dan personaliti. Paradigma Kristen bagi seorang guru PAK tercermin melalui sikap dalam bekerja dengan segenap kemampuan diri dalam memotivasi peserta didik dalam hal belajar dan memahami kebenaran yang hakiki. Dengan suatu pengertian bahwa guru PAK 
harus dapat menjadi sahabat dalam proses pembelajaran agar dapat melakukan pendekatan individu secara baik dan meningkatkan kemampuan belajar kea rah yang lebih baik. Dalam perspektif pengembangan sumber daya manusia, menjadi profesional adalah satu kesatuan antara konsep personaliti dan integritas yang dipadupadankan dengan skil atau keahliannya. Sehubungan dengan hal tersebut, maka seorang yang telah memilih guru sebagai profesinya, ia harus menekuni dan menyayangi pekerjannya serta mampu mengembangkan kinerja mengajarnya dengan inovasi yang berkualitas.

Ada tiga faktor pokok yang sangat berpengaruh terhadap penampilan guru dalam mengelola pengajaran, ketiga faktor tersebut adalah sebagai berikut: (1) Pandangan guru yang bersangkutan terhadap profesi guru. (2) Bagaimana guru tersebut menyikapi tugas sebagai guru. (3) Seberapa kemampuan umum yang dimiliki oleh guru mendukung tugas sebagai guru. ${ }^{19}$

Ketiga faktor yang telah disebutkan di atas, jika ditinjau dari kepentingan memang sudah urut. Pertama yang harus ada bagaimana pandangan terhadap profesi guru, jika sudah memandang profesi guru sebagai profesi yang rendah walaupun mempunyai pandangan yang luhur terhadap jabatan guru kemampuan yang dimiliki akan diberikan secara optimal mungkin serta dapat menyikapi tugas dengan baik. Ketiga yang tidak kalah pentingya adalah kemampuan yang dimiliki oleh guru mudah dipahami. Kurangnya kemampuan pada diri guru akan dapat menghambat gerak guru dalam menyampaikan penjelasan.

Untuk menetapkan profesi, maka guru harus mempunyai kompetensi,

\footnotetext{
${ }^{19}$ Suharsimi Arikunto. Op.Cit., 223.
}

dengan menguasai kompetensi, membuktikan bahwa profesi guru tidak mudah dicapai oleh setiap orang dan dapat dijadikan jaminan bahwa guru tersebut dapat menjalankan profesinya dengan baik. Berbagai organisasi kependidikan banyak mengemukakan. Dalam bukunya yang berjudul: Pendidikan Guru: Konsep dan Strategi, Hamalik berpendapat bahwa yang dimaksud dengan profesionalisme itu adalah sebagai berikut: Profesi itu pada hakikatnya adalah suatu pernyataan atau suatu janji terbuka, bahwa seseorang akan mengabdikan dirinya kepada suatu jabatan atau pelajaran dalam arti biasa, karena orang tersebut merasa terpanggil untuk menjabat pekerjaan itu. ${ }^{20}$

Pengertian di atas menunjukkan bahwa dengan profesi berarti seseorang membuat pernyataan dan janji pada dirinya bahwa ia melakukan pekerjaan itu karena didasari oleh suatu perjanjian jiwa. Oleh karena pekerjaan itu didasari karena perjanjian jiwa, maka ia akan komit terhadap pelajaran. Ia akan bekerja dengan tekun, dan dengan sepenuh hati, dan bekerja secara maksimal dan dan hasilnya akan optimal pula. Hal ini terjadi karena pekerjaan itu sendiri dengan pengetahuan, keterampilan maupun dengan sikap pribadinya. Seseorang yang bekerja tidak didasarkan pada pengetahuan, keterampilan, maupun dengan sikap pribadinya sudah barang tentu sudah tidak akan cekatan melakukan tugas-tugas pekerjaannya. Oleh karena itu, dalam penempatan serasa oleh pekerjaannya hendaknya dilakukan dengan prinsip ; "The right man on the right place" yang artinya tempat orang yang tepat pada tempat yang tepat. Agar demikian, akan dapat tercipta suatu optimalisasi dalam bekerja. Sedangkan pengertian profesi menurut H. Fank H. Blackington sebagai

\footnotetext{
${ }^{20}$ Oemar Hamalik, Pendidikan Guru: Konsep dan Strategi (Bandung: Mandar Maju), 1.
} 
berikut: "A profession may defined most simply as a vocation which is organized, imcompletly, no doubt, but geneanly, for the perfomance of function. ",21

Hakikat profesi adalah suatu pernyataan atau suatu janji terbuka. Suatu janji yang dikemukakan tenaga profesional tidak sama dengan yang dikemukakan non profesional. Pernyataan profesional mengandung makna terbuka yang sungguh-sungguh, yang keluar dari lubuk hatinya.

Persatuan Guru Republik Indonesia (PGRI) menyadari bahwa pendidikan merupakan pengabdian yang berjiwa Pancasila dan UUD 1945, maka guru Indonesia terpanggil untuk menunaikan karyanya sebagai guru. Kode etik guru Indonesia tersebut adalah sebagai berikut:

1. Guru berbakti membimbing anak didik seutuhnya untuk membentuk manunsia pembangunan yang ber-Pancasila.

2. Guru memiliki kejujuran profesional dalam menerapkan kurikulum sesuai dengan kebutuhan anak didik masingmasing.

3. Guru mengadakan komunikasi terutama dalam menghindari dari segala bentuk penyalahgunaan.

4. Guru menciptakan suasana kehidupan sekolah dan memelihara hubungan dengan orangtua murid sebaik-baiknya bagi kepentingan anak didik.

5. Guru memelihara hubungan baik dengan masyarakat di sekitar sekolah maupun masyarakat yang luas untuk kepentingan pendidikan.

6. Guru secara sendiri-sendiri dan atau bersama-sama berusaha mengembangkan dan meningkatkan mutu profesinya.

7. Guru menciptakan dan memelihara hubungan antar sesama atau guru baik

${ }^{21}$ Ibid., 3. berdasarkan lingkungan kerja maupun di dalam hubungan keseluruhan.

8. Guru secara bersama-sama memelihara, membina dan meningkatkan mutu organisasi guru profesional sebagai sarana pengabdiannya.

9. Guru melaksanakan segala ketentuan yang merupakan kebijaksanaan pemerintah dalam bidang pendidikan. $^{22}$

Pemahaman ini memberikan suatu pengertian bahwa kode etik guru merupakan wujud dari sikap dan perilaku yang bertujuan menempatkan guru sebagai profesi terhormat, mulia, dan bermartabat yang dilindungi undang-undang dalam melakukan setiap pekerjaan, yang di dalamnya pasti terdapat aturan-aturan yang mengikat. Aturan tersebut dibuat agar suatu profesi dapat berjalan sesuai dengan apa yang telah disepakati. Profesi menuntut kemampuan membuat keputusan yang tepat dan kemampuan membuat kebijaksanaan yang tepat.

Menurut Suharsimi Arikunto, bertumpu dari definisi profesi dapat dilihat bahwa:

1. Di dalam suatu pekerjaan profesional diperlukan teknik serta prosedur yang bertumpu pada landasan intelektual yang dipelajari dari suatu lembaga, kemudian diterapkan di masyarakat untuk pemecahan suatu masalah.

2. Seorang pekerja professional dapat dibedakan dengan seseorang teknisi dalam hal pemilihan filosofi yang kuat untuk mempertanggungjawabkan pekerjaannya, serta mantap dalam menyikapi dan melaksanakan pekerjaannya.

3. Seorang yang bekerja berdasarkan profesinya memerlukan teknik dan prosedur yang ilmiah serta memiliki

\footnotetext{
${ }^{22}$ Sriyono et al, Teknik Bekajar Mengajar dalam CBSA (Jakarta: Rineka Cipta), 72.
} 
dedikasi yang tinggi dalam menyikapi lapangan pekerjaan yang berdasarkan atas sikap seorang ahli. ${ }^{23}$

Dalam suatu profesi memiliki ciriciri khusus yang harus dimengerti seorang guru agar menyandang profesinya harus dapat bertanggungjawab sesuai atauran yang ada. Menurut Robert W. Richey suatu pemahaman tentang ciri-ciri profesi dan syarat-syarat suatu profesi: sebagai berikut:

1. Lebih mementingkan pelayanan kemanusiaan yang ideal dibandingkan dengan kepentingan pribadi.

2. Seorang pekerja professional, secara relatif memerlukan waktu yang panjang untuk mempelajari konsepkonsep serta prinsip-prinsip pengetahuan khusus yang mendukung keahliannya.

3. Memilki kualifikasi tertentu untuk memasuki profesi tersebut serta mampu untuk mengikuti perkembangan dalam pertumbuhan jabatan

4. Memiliki kode etik yang mengatur tingkah laku, sikap dan cara kerja.

5. Membutuhkan suatu kegiatan intelektual yang tinggi

6. Adanya organisasi yang dapat meningkatkan standar pelayanan, disiplin dari dalam profesi, serta kesejahteraan anggotanya.

7. Memberikan kesempatan untuk kemajuan, spesialisasi dan kemandirian.

8. Memandang profesi sebagai suatu karir hidup dan menjadi seorang anggota yang permanen. ${ }^{24}$

Berdasarkan pengertian dan ciriciri profesi tersebut, maka guru dapat dikategorikan sebagai profesi. Profesi guru pada saat ini masih merupakan sesuatu yang ideal bila dibandingkan dengan

23 Suharsini Arikunto, Manajemen Pengajaan Secara Manusiawi (Jakarta: Rineka Cipta), 233. profesi pada bidang lain. Bila profesi lain menjalankan tugasnya selalu dilandasi kemampuan dan keahlian yang ditunjang dengan konsep dan teori yang pasti, maka profesi guru tidaklah demikian. Kenakalan antara satu peserta didik dengan yang lainnya, memerlukan penanganan yang berbeda. Sekolah adalah suatu lembaga profesional yang membentuk peserta didik menjadi manusia yang berkepribadian matang dan tangguh dapat dipertanggungjawabkan dan bertanggungjawab atas dirinya dan masyarakat. Itu sebabnya, guru harus dididik dalam profesi kependidikan agar memiliki kompetensi yang diperlukan untuk melaksanakan tugas dan fungsinya secara efisien dan efektif.

Sesuai dengan hakekat profesi, maka sudah jelas bahwa pekerjaan guru harus dilakukan oleh seorang selaku guru, bahwa pekerjaan guru adalah penuh pengabdian pada masyarakat dan pekerjaan guru perlu memiliki kode etik tertentu. Lebih lanjut, Roestiyah berpendapat bahwa:

1. Lapangan kerja keguruan atau kependidikan bukan merupakan suatu lapangan kerja rutin yang dapat dilakukan karena pengulanganpengulangan atau pembiasaan. Lapangan kerja ini pun tidak dapat dilaksanakan secara amatirisme, lebih-lebih atas dasar coba-coba atau trial and erros. Lapangan kerja ini merupakan perencanaan yang mantap suatu manajemen yang memperhitungkan komponenkomponen sistemnya.

2. Lapangan kerja ini memerlukan dukungan ilmu atau teori yang akan memberikan konsepsi teoritis ilmu kependidikan dengan cabangcabangnya.

${ }^{24}$ Ibid, 236. 
3. Lapangan kerja ini memerlukan waktu pendidikan dan latihan yang lama, berupa pendidikan dasar (basic education) untuk taraf sarjana ditambah dengan pendidikan profesionalnya. $^{25}$

Oleh karena itu, dunia pendidikan adalah dunia professionalis, maka berbagai upaya untuk membina dan mengembangkan profesi harus terus dikembangkan Kepala Sekolah sebagai administrator pendidikan hendaknya membantu guru-guru dalam melaksanakan tugas profesionalnya. Dengan demikian sekolah memerlukan tenaga administrator yang baik yang dapat mengembangkan potensi para guru, mempunyai motivasi tinggi, memperlakukan bawahan dengan baik dan berlaku sebagai manajer.

Tugas guru sangatlah kompleks yang berhubungan dengan sejumlah komponen pengajaran sebagai suatu system. Pembinaan guru tidak sekedar meminta guru untuk membaca buku-buku pelajaran sebanyak mungkin untuk disampaikan kepada murid, tetapi mengembangkan sebuah model tugas pengajaran yang interdependensi. Menurut Anderson ada lima perangkat tugas seorang guru yaitu:

1. Menyeleksi kurikulum

2. Mendiagnosis kesiapan, gaya dan minat murid

3. Merancang program

4. Merencanakan pengelolaan kelas

5. Melaksanakan pengajaran di kelas. ${ }^{26}$

Untuk menetapkan profesi sebagai guru, maka harus mempunyai kompetensi. Dengan menguasai kompetensi, membuktikan bahwa profesi guru tidak mudah dicapai oleh setiap orang. Berbagai organisasi kependidikan banyak mengemukakan berbagai kompetensi guru

25 Roestiyah N. K, Masalah-Masalah Ilmu Keguruan (Jakarta: Bina Aksara), 174.

${ }^{26}$ Ibraham Bafadal, Supervisi Pengajaran (Jakarta: Bumi Aksara), 23. benar-benar harus dikuasai. Diantaranya yang dikeluarkan oleh P3G sebagai berikut:

1. Menguasai bahan

2. Mengelola program belajar-mengajar

3. Mengelola kelas

4. Menggunakan media atau sumber

5. Menguasai landasan-landasan kependidikan

6. Mengelola interaksi belajar mengajar peserta didik

7. Menilai prestasi peserta didik untuk kepentingan belajar. ${ }^{27}$

Kompetensi guru dirumuskan pula oleh Lembaga Pendidikan IKIP Jakarta antara lain:

1. Merumuskan tujuan interaksional

2. Memanfaatkan sumber-sumber matreri dan belajar

3. Mengorganisasikan materi pelajaran

4. Membuat, memilih, dan melaksanakan metode pendidikan dengan tepat.

5. Menguasai, memilih dan melaksanakan metode penyampaian yang tepat untuk pelajaran tertentu

6. Mengetahui dan menggunakan assemen peserta didik

7. Memanage interaksi belajar mengajar, sehingga efektif dan tidak membosankan peserta didik.

8. Evaluasi dan pengadministrasian

9. Mengembangkan semua kemampuan yang telah dimilikinya ke tingkat yang lebih daya guna dan berhasil guna. ${ }^{28}$

Setelah melihat rumusan kompetensi guru, maka dapat disimpulkan bahwa sebenarnya kompetensi sebagai guru adalah mengajar. Mengajar adalah segala upaya yang disengaja dalam rangka memberikan stimulus, bimbingan dan dorongan kepada peserta didik agar terjadi proses belajar mengajar. Dengan kompetensi yang dimiliki oleh guru dalam

${ }^{27}$ Roestiyah N.K., Op.Cit., 7.

${ }^{28}$ Ibid., 8. 
menjalankan tugasnya maka proses belajar mengajar akan berjalan lebih optimal.

\section{E. Hakikat Prestasi}

Menurut Kamus Besar Bahasa Indonesia, disebutkan bahwa yang dimaksud dengan prestasi adalah "hasil yang telah dicapai (dari yang telah dilakukan, dikerjakan, dan sebagainya." 29 Pengertian ini menunjukkan bahwa yang dimaksud dengan prestasi adalah hasil yang dicapai oleh seseorang. Besarnya hasil itu tergantung dari tingkat upaya maupun tingkat kepandaian seseorang dalam melakukan sesuatu. Artinya kalau tingkat upaya seseorang dalam bekerja cukup tinggi, dan tingkat kepandaian juga tinggi, maka akan berdampak dirinya pada saat belajar. Dengan belajar (tekun), maka kepandaian akan meningkat, sedangkan menurut Khasan dalam Djamarh berpendapat bahwa yang dimaksud prestasi itu adalah "apa yang dinyatakan hasil pekerjaan, hasil yang menyenangkan hati diperoleh dengan jelas keuletan bekerja”. 30 Dengan demikian yang dimaksud dengan prestasi itu adalah sesuatu hasil yang menyenangkan hati yang bersangkutan.

\section{F. Hakikat Belajar}

Untuk memahami apa yang dimaksud dengan belajar, berikut penulis akan mengungkapkan beberapa pendapat sebagai berikut: Pertama, dalam belajar faktor pendukung atau pengertian (insight) merupakan faktor yang penting. Dengan belajar dapat memahami / mengerti hubungan antara pengetahuan dan pengalaman. Kedua, dalam belajar pribadi atau organisme menunjang peranan yang

\footnotetext{
${ }^{29}$ Kamus Besar Bahasa Indonesia, Op. Cit., 787.

${ }^{30}$ Syaiful Bahri Djamarah, Prestasi dan

Kompetensi Guru, (Surabaya: Usaha Nasional, 1994), 19.

31 M. Ngalim Purwanto, Psikologi Penelitian

(Bandung: Remaja Rosdakarya, 1990), 101.
}

paling sektoral. Belajar tidak hanya dilakukan secara reaktif-mekanistis belaka, tetapi dilakukan dengan sadar, bermotif dan bertujuan. ${ }^{31} \mathrm{Jadi}$, dengan belajar, seseorang akan mengalami sesuatu perubahan baik dalam pengetahuan, pengertian-pengertian, maupun sikapnya sebagaimana diungkapkan oleh Bronbach berikut ini, bahwa: "Dengan belajar ditunjukkan oleh suatu perubahan tingkah laku sebagai hasil dari pengalaman"32 Jadi, pengertian belajar menunjukkan bahwa kehidupan manusia hendaknya terus menerus belajar, agar dengan demikian tingkah lakunya berubah ke arah yang lebih baik dan lebih berkualitas, sehingga dapat membuat hidupnya menjadi lebih mudah.

\section{G. Hakikat Prestasi Belajar}

Nawawi berpendapat bahwa yang dimaksud dengan prestasi belajar ialah "tingkat keberhasilan peserta didik dalam mempelajari materi pelajaran di sekolah yang di nyatakan dalam bentuk skor yang diperoleh dari hasil tes mengenai jumlah pelajaran tertentu." 33 Pendapat ini menunjukkan bahwa yang dimaksud dengan prestasi belajar adalah tingkat keberhasilan peserta didik dalam mempelajari materi pelajaran di sekolah. Bentuk prestasi belajar ini adalah berupa skor yang diperoleh melalui hasil tes terhadap pelajaran-pelajaran yang telah diikuti oleh peserta didik tersebut. Dengan demikian, apabila prestasi belajar seorang peserta didik tinggi, maka hal itu menunjukkan bahwa tingkat keberhasilan peserta didik tersebut dalam mengikuti materi pelajaran juga tinggi. Demikian sebaliknya, apabila prestasi belajar peserta

\footnotetext{
32 E. Usman Effendi, Pernyataan Psikologi (Bandung: Angkasa), 102.

${ }^{33}$ Hadari Nawawi, Pengaruh Hubungan Manusia Dikalangan Murid terhadap Prestasi Peserta didik Belajar, Analisa Pendidikan, tahun II. No. 1. Jakarta. hal. 100.
} 
didik di sekolah rendah, maka perlu upayaupaya perbaikan yang harus dilakukan oleh sekolah. Oleh karena itu, menurut Sujono, setiap guru harus dapat melakukan penelitian tentang kemajuan yang dicapai oleh para peserta didik, baik secara iluminitif-observatif (dilakukan dengan pengamatan yang terus menerus tentang pembahasan dengan kemajuan yang dicapai peserta didik) mampu secara struktural obyektif (pemberian skor angka atau nilai). ${ }^{34}$ Hal ini memberikan suatu pemahaman bahwa guru diharapkan mampu melakukan penelitian melalui suatu survei dalam tindakan belajar peserta didik, sehingga evaluasi yang berkaitan dengan penilaian pada akhir pembelajaran dapat terwujud sesuai tujuan pembelajaran.

Lebih lanjut lagi Suharsimi berpendapat bahwa yang dimaksudkan dengan prestasi belajar adalah sebagai berikut: "Prestasi belajar adalah angka yang menunjukkan taraf keberhasilan belajar peserta didik yang sebenarnya setelah melalui proses belajar yang diperoleh dari pengukuran tes akhir dan tes awal." 35 Maksud dari pemahaman ini memberikan suatu pengertian bahwa prestasi peserta didik menunjukkan suatu tingkatan belajar dari awal hingga akhir dan mencapai suatu keberhasilan dicapai sesuai tujuan yang diharapkan.

\section{H. Kerangka Konseptual}

Salah satu faktor penting dalam mewujudkan tingkat prestasi belajar peserta didik adalah profesionalisme guru dalam mengajar. Guru yang secara profesional mengajar materi pelajaran akan dapat membuat peserta didik lebih mudah dan cepat memahami pelajaran yang diajarkan. Tingkat pemahaman

34 Nana Sudjana, Dasar-Dasar Proses Belajar Mengajar (Bandung: Sinar Baru Algensindo, 2013), 21. peserta didik terhadap mata pelajaran yang diikutinya akan tercermin dalam prestasi belajarnya. Oleh karena itu agar prestasi belajar peserta didik menjadi baik, maka dibutuhkan kemampuan seorang guru yang profesional dalam proses belajar mengajar.

\section{Kesimpulan}

Profesi adalah pekerjaan, namun tidak semua pekerjaan adalah profesi. Profesi mempunyai karakteristik yang membedakannya dari pekerjaan lain. Profesi adalah pekerjaan yang membutuhkan pelatihan dan penguasaan terhadap suatu pengetahuan khusus. Suatu profesi biasanya memiliki asosiasi profesi, kode etik, serta proses sertifikasi dan lisensi yang khusus untuk bidang profesi tersebut.

Pendidikan menghasilkan perubahan, dan perubahan berdampak bagi masa depan setiap peserta didik yang terlibat dalam proses pembelajaran. Salah satu faktor penting yang dapat menentukan keberhasilan belajar mengajar pada suatu sekolah adalah tingkat profesionalisme guru dalam menjalankan tugas-tugas pengajarannya. Jadi dengan belajar, seseorang akan mengalami sesuatu perubahan baik dalam pengetahuan, maupun pengertian-pengertian, Untuk mencapai tujuan pendidikan nasional yang diwujudnyatakan melalui setiap sekolahsekolah yang ada, maka pemerintah dengan berbagai upaya yang dilakukan meningkatkan profesionalisme guru dengan cara pemberian sertifikasi guru, pengangkatan tenaga honorer menjadi Calon Pegawai Negeri Sipil (CPNS), dan sebagainya.

Salah satu poin penting yang harus dilaksanakan oleh guru PAK dalam proses pembelajaran di sekolah adalah dapat

35 Suharsini Arikunto, Dasar-Dasar Evaluasi Pendidikan (Jakarta: Bina aksara), 103 . 
menghasilkan prestasi bagi setiap peserta didik di bawah tanggungjawabnya. Kemampuan seorang guru PAK dalam tugas dan tanggungjawabnya, merupakan bagian dari profesionalisme kinerja guru. Bentuk prestasi belajar ini adalah berupa skor yang diperoleh melalui hasil tes terhadap pelajaran-pelajaran yang telah diikuti oleh peserta didik tersebut. Dengan demikian, apabila prestasi belajar seorang peserta didik tinggi, maka hal itu menunjukkan bahwa tingkat keberhasilan peserta didik tersebut dalam mengikuti materi pelajaran juga tinggi. Demikian sebaliknya, apabila prestasi belajar peserta didik di sekolah rendah, maka perlu upayaupaya perbaikan yang harus dilakukan oleh sekolah.

\section{J. Referensi}

Alkitab, (Jakarta: Lembaga Alkitab Indonesia, 2010).

Ahmad, Djauzak. Petunjuk Peningkatan Mutu Pendidikan di Sekolah Dasar. Depdikbud. Dirjen Pendidikan Dasar dan Menengah. Direktorat Dasar.

Arikunto, Suharsimi. Management Pengajaran secara Manusiawi. Jakarta: Rineka Cipta.

Dasar-Dasar Evaluasi

Pendidikan. Jakarta: Bina aksara. Manajemen Pengajaan Secara Manusiawi. Jakarta: Rineka Cipta.

Bafadal, Ibraham. Supervisi Pengajaran. Jakarta: Bumi Aksara. 23.

Effendi, E. Usman. Pernyataan Psikologi. Bandung: Angkasa. Hamalik, Oemar. Pendidikan Guru: Konsep dan Strategi. Bandung: Mandar Maju.

Idris, H. Zahara dan Jamal, H. Lisma. Pengantar Pendidikan. Jilid I Jakarta: Grasindo.

GP, Harianto. Pendidikan Agama Kristen Dalam Alkitab \& Dunia Pendidikan
Masa Kini (Yogyakarta: ANDI, 2012).

Nawawi, Hadari. Pengaruh Hubungan Manusia Dikalangan Murid Terhadap Prestasi Peserta didik Belajar, Analisa Pendidikan, tahun II. No. 1. Jakarta.

Nur, H. Agustiar Syah. Profesionalisme Manajemen Tenaga Pendidikan. Padang: Agustus 1 makalah ini disampaikan pada Temu Ilmiah Manajemen Pendidikan.

Purwanto, M. Ngalim. Psikologi Penelitian Bandung: Remaja Rosdakarya, 1990.

Roestiyah N. K. Masalah-Masalah Ilmu Keguruan. Jakarta: Bina Aksara.

Sahertian, Piet A. Profil Pendidik Profesional. Yogyakarta: Andi Offset 1994.

Sardiman. A. M. Interaksi dan Motivasi Belajar Mengajar. Jakarta: Rajawali Pers.

Sudjana, Nana. Dasar-Dasar Proses Belajar Mengajar. Bandung. Sinar Baru Algensindo, 2013.

Cara Belajar Peserta didik Aktif dalam Proses Belajar Mengajar. Bandung: Rosda Karya, 2009.

Sutisna, Oteng. Profesionalisme Pekerjaan Kepala Sekolah. Bandung: Depdikbud, 2009. Administrasi Pendidikan Dasar Teoritis untuk Praktek Profesional. Bandung: Penerbit Angkasa, 2016.

Sriyono et al. Teknik Bekajar Mengajar dalam CBSA. Jakarta: Rineka Cipta.

Sukamto, Dkk. Pengembanga Profesi Guru Secara Berkesinambungan . from.http://www.infodiknas.com/21 7-pengembangan-profesi-gurusecara-berkesinambungan-sebagaistrategi-nasional-pendukungsertifikasi-guru/ Diakses pada 
Jurnal Pendidikan Agama Kristen SHANAN

Volume 3 Nomor 2 Tahun 2019 hal. 77-94

tanggal 24 Juli 2019, pukul 19:15

WIB.

Sutaryadi. Administrasi Pendidikan Riset dan Prakits. Surabaya: Usaha Nasional.

Syaiful Bahri Djamarah, Prestasi dan Kompetensi Guru, (Surabaya: Usaha Nasional, 1994)

Usman, Moch. Uzer. Menjadi Guru Profesional. Bandung: Rosda Karya. 